F307

\title{
結晶質シリカ気管内注入によるラット肺組織での CCSP発現の变化
}

廣橋 雅美 ${ }^{1}$ 、森本 泰夫 ${ }^{1}$ 、長友 寛子 ${ }^{1}$ 、大藪 貴子 ${ }^{1}$ 、大神 明 $^{1}$ 、大和 浩 ${ }^{1}$ 、 黑田 香織 ${ }^{1}$ 、永㴊 祥大 ${ }^{1}$ 、東 敏昭 ${ }^{1}$ 、田中 勇武 ${ }^{1}$

${ }^{1}$ 産業医科大学 産業生態科学研究所

【はじめに】末梢気道に局在するクララ緗胞は、炎症抑制蛋白を産生し、気道賃害後も修復に関与する成長因 子を産生し、線維化に抑制的に作用することが考えられる。このクララ細胞が特異的に産生する Clara Cell Secretory Protein （CCSP）は 10kDa の分泌蛋白で、フォスフォリパーゼ $\mathrm{A} 2$ や、炎症性サイトカインの抑制 を介して、炎症・線維化を抑制すると考えられている。ヒトでの肺線維症において BALF 中の CCSP が減少 する事か報告されており、この炎症・線維化抑制遭伝子の低下か、、線維化を進行させたと考えられる。よつ て、粉じんによる肺の線維化においても CCSP が関与するか注目し、検討を行った。

【目的】我々は今までに結晶質シリカによる肺賃害にCCSP が関与するか、RNA レベルでの遭伝子発現につ いて検討を行ってきた ”。今回は蛋白レベルで発現を検討した。

(方法】結晶質シリカ (Min-U-Sil5,USA) $2 \mathrm{mg}$ を生食 $0.4 \mathrm{ml}$ に懸濁させ、Wistar 系雄性ラット 10 週龄に気管内 注入し、3 日、 1 週間、1 ケ月、3 3 月、6 6 ケ月後に各群 5 匹ずつ解剖。右肺より蛋白を抽出、SDS-PAGE 法に て蛋白質を分離、セミドライ式ブロッティングを施行、ラットCCSP抗体を用いて蛋白発現を解析した。 【結果】 lmg 注入群では 1 ケ月、3 3 月で有意に低下し、 $2 \mathrm{mg}$ 注入群では 3 日、 1 週間、1 ケ月後に低下した。 しかし、 $2 \mathrm{mg}$ 注入群において 6 ヶ月後では方進した。その他の期間では、コントロール群と比較して有意な 差は認められなかった。

【とめと考察】本試験において、結晶賀シリカの懪露は、肺組織の CCSP 発現を急性期では蛋白レベルの みならず RNA レベルにおいて低下させた。慢性期では RNA レベルと蛋白レベルの結果に遠いが見られた。 この相違に関しては、結晶質シリカ曝露 3 ヶ月後において RNA レベルでの増加を認めていることより、蛋 白レベルのて進は CCSP 産生允進状態が 6 ヶ月近くまで継続したことが侾えられた。以上の結果より、急性 期においてCCSP 蛋白、RNA レベルで低下を認めたことは、粉じんによる肺賃害にCCSP の低下が関与した ことを示唆している。

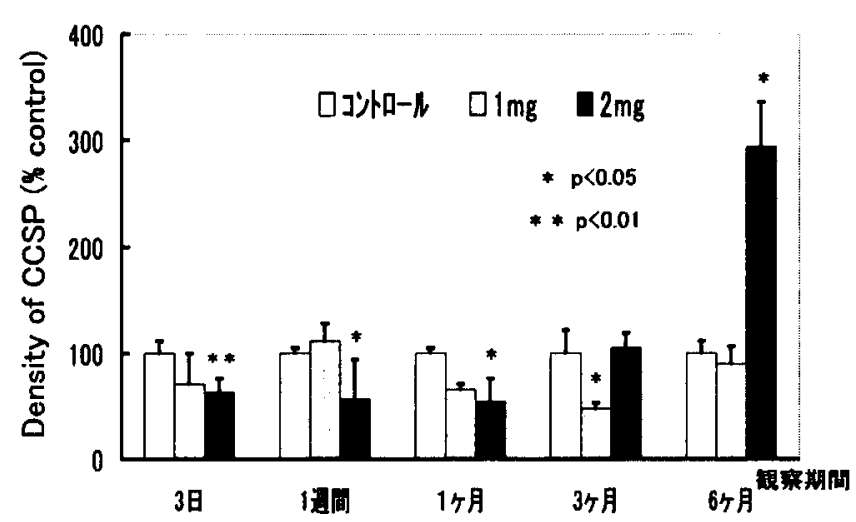

图 結晶算シリカ䀧露による肺組辕でのCCSP発現
表 結晶質シリカ曝蕗におけるCCSP発現

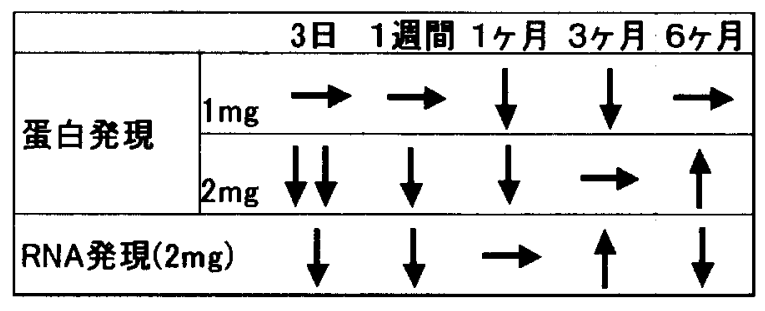

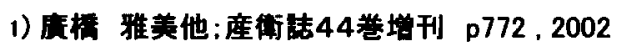

